\title{
Combining patient proteomics and in vitro cardiomyocyte phenotype testing to identify potential mediators of heart failure with preserved ejection fraction
}

Roseanne Raphael ${ }^{1 \dagger}$, Diana Purushotham ${ }^{2 \dagger}$, Courtney Gastonguay ${ }^{1,2,3}$, Marla A. Chesnik ${ }^{5}$, Wai-Meng Kwok ${ }^{6}$, Hsiang-En Wu' ${ }^{6}$, Sanjiv J. Shah7 ${ }^{7}$ Shama P. Mirza ${ }^{5}$ and Jennifer L. Strande ${ }^{1,2,3,4^{*}}$

\begin{abstract}
Background: Heart failure with ejection fraction (HFpEF) is a syndrome resulting from several co-morbidities in which specific mediators are unknown. The platelet proteome responds to disease processes. We hypothesize that the platelet proteome will change composition in patients with HFpEF and may uncover mediators of the syndrome.

Methods and results: Proteomic changes were assessed in platelets from hospitalized subjects with symptoms of $\operatorname{HFpEF}(n=9)$, the same subjects several weeks later without symptoms $(n=7)$ and control subjects $(n=8)$. Mass spectrometry identified 6102 proteins with five scans with peptide probabilities of $\geq 0.85$. Of the 6102 proteins, 165 were present only in symptomatic subjects, 78 were only found in outpatient subjects and 157 proteins were unique to the control group. The S100A8 protein was identified consistently in HFpEF samples when compared with controls. We validated the fining that plasma S100A8 levels are increased in subjects with HFpEF (654 \pm 391$)$ compared to controls (352 \pm 204$)$ in an external cohort $(p=0.002)$. Recombinant S100A8 had direct effects on the electrophysiological and calcium handling profile in human induced pluripotent stem cell-derived cardiomyocytes.

Conclusions: Platelets may harbor proteins associated with HFpEF. S100A8 is present in the platelets of subjects with HFpEF and increased in the plasma of the same subjects. We further established a bedside-to-bench translational system that can be utilized as a secondary screen to ascertain whether the biomarkers may be an associated finding or causal to the disease process. S100A8 has been linked with other cardiovascular disease such as atherosclerosis and risk for myocardial infarction, stroke, or death. This is the first report on association of S100A8 with HFpEF.
\end{abstract}

Keywords: Platelet proteome, Heart failure with preserved ejection fraction, Inflammation, S100A8, Induced pluripotent stem cell-derived cardiomyocytes

\section{Background}

The platelet proteome is an untapped resource for identifying proteins that may reflect a disease process. Platelets are easily accessible and free from major highly abundant proteins making them an attractive model for proteomic

\footnotetext{
*Correspondence: jstrande@mcw.edu

${ }^{\dagger}$ Roseanne Raphael and Diana Purushotham contributed equally to this work

${ }^{4}$ Present Address: MEB/CVC 4579, 8701 Watertown Plank Road,

Milwaukee, WI 53226, USA

Full list of author information is available at the end of the article
}

studies. Platelets change the composition of their proteins in diseases such as Alzheimer's, cancer, diabetes, coronary artery disease and acute coronary syndrome [1-4]. Platelets are largely under-studied in heart failure, yet evidence indicates that both platelet function $[5,6]$ and platelet-derived proteins such as adhesion molecules and the natriuretic peptide receptor-C [7-10] are altered in heart failure. Therefore, changes in the platelet proteome may allow for the identification of proteins that influence the disease process in heart failure. 
Heart failure with preserved ejection fraction (HFpEF) affects almost $50 \%$ of patients with heart failure and is increasing in prevalence [11], yet the pathophysiological mechanisms are poorly understood. HFpEF is associated with diabetes, hypertension, renal dysfunction, atrial fibrillation and obesity. The systemic inflammatory state induced by these co-morbidities is predictive of HFpEF $[12,13]$. Platelets are both contributors and responders of inflammatory processes [14]. Considering there are no targeted therapies for HFpEF and morbidity and mortality are high, it is paramount to identify biomarkers associated with HFpEF and clarify their mechanistic role in clinical heart failure in order to develop targeted treatments. Consequently, by examining the platelet proteome of subjects with HFpEF, there is the potential to identify proteins that may provide insight into the disease mechanisms.

We established a novel bed-to-bench translational system to identify potential mediators of HFpEF using both platelet proteome analysis and mechanistic studies in induced pluripotent stem cell-derived cardiomyocytes. The broad utility of this strategy is to incorporate bioactivity studies into guiding the selection of proteins from proteomic studies for further investigation. We sought to compare the platelet proteome among subjects with HFpEF in the uncompensated (hospitalized) state, compensated (outpatient) state, and controls combined with validation in plasma samples from an external cohort and bioactivity studies using human induced pluripotent stem cell (iPSC)-derived cardiomyocytes. We hypothesized that [1] platelet proteomic analysis would successfully identify a protein associated with HFpEF, and [2] human iPSC-derived cardiomyocytes treated with recombinant proteins could serve as further validation by demonstrating phenotypic changes in cardiomyocyte calcium handling, which is altered in HFpEF.

\section{Methods}

\section{Study population}

For the discovery phase, subjects $\geq 50$ years old presenting with New York Heart Association class II-III heart failure symptoms, a left ventricular ejection fraction (LVEF) $>50 \%$, echocardiographic evidence of diastolic dysfunction and increased LV filling pressure were evaluated at the Medical College of Wisconsin between June 2012 to December 2013 for participation in this study. Increased LV filling pressures were defined as $\mathrm{E} / \mathrm{e}^{\prime} \geq 15$, or $\mathrm{E} / \mathrm{e}^{\prime} \geq 8$ and $\leq 15$ with either a $\mathrm{BNP} \geq 200 \mathrm{pg} / \mathrm{ml}$ or a left atrial (LA) volume index $>40 \mathrm{ml} / \mathrm{m}^{2}$. Subjects were excluded if they had a clinical condition that potentially changed the platelet or plasma proteomic profile independent of HFpEF such as uncontrolled diabetes, an active infection or inflammatory disorder, chronic renal failure requiring dialysis, severe liver disease, malignancy, acute myocardial infarction, chronic obstructive pulmonary disease requiring steroids, or recent surgical or invasive cardiac procedures. Subjects were excluded if they had other cardiac causes for their symptoms such as severe valvular disease, amyloidosis, or hypertrophic cardiomyopathy. Blood was drawn from the nine subjects enrolled in the study (HFpEF hospitalized group). Five of these subjects (HFpEF outpatient group) returned $\geq 2$ weeks after discharge for second blood draw. Subjects with an LVEF $\geq 50 \%$ and without evidence of increased LV filling pressures served as the control group.

For further biomarker validation, an additional set of 25 HFpEF subjects and 18 age and co-morbidity matched control subjects were recruited from Northwestern University. All subjects gave written informed consent to participate in the study. The Institutional Review Board at the Medical College of Wisconsin and Northwestern University approved the respective study protocols, which conformed to the principles of the Declaration of Helsinki.

\section{Reagents}

Supplies and other reagents were purchased from SigmaAldrich (St. Louis, MO) unless specified. Recombinant S100A8 was purchased from Creative BioMart (Shirley, NY).

\section{Platelet preparation}

Blood was separated into serum and platelet fractions. Platelets were extensively washed in buffer (45 mM sodium citrate, $25 \mathrm{mM}$ citric acid, $80 \mathrm{mM}$ D-glucose). During all steps, care was taken to avoid activation of platelets. Flow cytometry with anti-CD41 (Life Technologies, Grand Island, NY) and anti-P-selectin (BioLegend, San Diego, CA) was performed to assess for platelet activation (Additional file: 1. Figure S1). Microscopy confirmation verified that the purified platelets had leukocyte and red blood cell contamination that was less than 0.02 and $1 \%$, respectively (Additional file: 2 . Figure S2).

\section{Global proteomic studies}

Platelets from individual samples were resuspended in lysis buffer (125 mM Tris pH 6.8, 4 \% SDS, $10 \%$ glycerol, $5 \% \beta$-mercaptoethanol, Roche Complete Protease Inhibitor, Thermo HALT Phosphatase Inhibitor Cocktail). After determining protein concentration, the protein sample was separated by 1-dimensional SDSPAGE gel (Bis-Tris 4-12 \%) with internal DNA markers as described in our earlier publication [15]. The gel was stained with indoine blue and divided into three pieces. The proteins were reduced with $100 \mathrm{mM}$ dithiotreitol (DTT) in $25 \mathrm{mM} \mathrm{NH}_{4} \mathrm{HCO}_{3}$ for $30 \mathrm{~min}$ at $56{ }^{\circ} \mathrm{C}$ and 
alkylated with $55 \mathrm{mM}$ iodoacetamide (IAA) in $25 \mathrm{mM}$ $\mathrm{NH}_{4} \mathrm{HCO}_{3}$ for $30 \mathrm{~min}$ at room temperature followed by trypsin digestion overnight. Peptides were extracted with $0.1 \%$ trifluoroacetic acid (TFA) and $70 \%$ acetonitrile $/ 5 \%$ TFA in water, respectively. Extracts were dried in a Speedvac and subsequently acidified to $0.1 \%$ TFA. The samples were desalted using a ZipTip (C18).

For biomarker discovery, all samples were subject to tandem mass spectrometry. Three injection replicates of each fraction (three fractions per sample) were run on an LTQOrbitrap Velos mass spectrometer (Thermo Scientific). For each injection replicate, $1.5 \mu \mathrm{l}$ sample was separated via C18 column over the course of a 150 min gradient from buffer A ( $2 \%$ acetonitrile, $98 \% \mathrm{H}_{2} \mathrm{O}, 0.1 \%$ formic acid) to buffer B (98\% acetonitrile, $2 \% \mathrm{H}_{2} \mathrm{O}, 0.1 \%$ formic acid). The gradient program began with $2 \mathrm{~min}$ at $98 \% \mathrm{~A}$, followed by a 3 min ramp to $95 \%$ A, a 115 min ramp to $60 \%$ $\mathrm{A}$, a $15 \mathrm{~min}$ ramp to $2 \% \mathrm{~A}, 3 \mathrm{~min}$ at $2 \% \mathrm{~A}, 2 \mathrm{~min}$ ramp to $98 \% \mathrm{~A}$, then a $10 \mathrm{~min}$ equilibration in $98 \% \mathrm{~A}$. MS1 scans were detected in the FTMS section of the Orbitrap Velos in profile mode at a resolution of 30,000 (full width of peak at half-maximum at $400 \mathrm{~m} / \mathrm{z}$ ). The ten most abundant parent ions from each MS1 scan were selected for fragmentation via collision induced dissociation. Results of SEQUEST searches against UniProt human database (version April 2013) and all nine runs of each sample were combined using Visualize software. Visualize software was also used to generate comparison data [16]. The protein lists include proteins identified with at least five scans that were observed with peptide probability $>0.85$.

\section{S100A8 expression}

S100A8 levels were determined using a S100A8 enzymelinked immunoassay kit from MBL International (Des Plaines, IL).

\section{Induced pluripotent stem cell induced-cardiomyocyte differentiation}

The induced pluripotent stem cell (iPSC) line used in this study was a generous gift from Dr. Stephan Duncan. This iPSC line was generated from human foreskin fibroblasts and previously characterized [17]. The iPSC line was maintained on Matrigel (BD Biosciences, San Jose, CA) in mTeSR-1 media (Stem Cell Technologies, BC, Canada) and differentiated into cardiomyocytes according to published protocols $[18,19]$. Differentiated cells were maintained in cardiomyocyte maintenance media (RPMI/B27; Life Technologies, Grand Island, NY). For all experiments, $35 \pm 5$ day old contracting cardiomyocytes were used.

\section{Electrophysiology}

Action potentials were recorded from the human iPSC-derived cardiomyocytes using the current clamp configuration of the patch clamp technique, as previously described [20, 21]. Briefly, patch pipettes were pulled from borosilicate glass capillaries (King Precision Glass, Claremont, CA) with a micropipette puller (PC-10; Harishige, Tokyo, Japan) and heat polished using a microforge (MF-830; Narishige). The pipette resistances ranged from 3-5 $\mathrm{M} \Omega$ when filled with the intracellular recording solution. This pipette solution contained $60 \mathrm{mM} \mathrm{K-gluta-}$ mate, $50 \mathrm{mM}$ KCL, $10 \mathrm{mM}$ HEPES, $1 \mathrm{mM} \mathrm{MgCl}$, $11 \mathrm{mM}$ EGTA, $1 \mathrm{mM} \mathrm{CaCl}_{2}$, and $5 \mathrm{mM} \mathrm{K}_{2}$-ATP (pH adjusted to 7.4 with $\mathrm{KOH}$ ). The extracellular bath solution contained $132 \mathrm{mM} \mathrm{NaCl}, 4.8 \mathrm{mM} \mathrm{KCl}, 1.2 \mathrm{mM} \mathrm{MgCl}{ }_{2}, 1.0 \mathrm{mM}$ $\mathrm{CaCl}_{2}, 5 \mathrm{mM}$ dextrose, and $10 \mathrm{mM}$ HEPES (pH adjusted 7.4 with $\mathrm{NaOH}$ ). Action potentials were recorded using a Multiclamp 700B amplifier and Digidata 1440A interface (Molecular Devices, Sunnyvale, CA). pClamp 10 software (Molecular Devices) was used for data acquisition and analysis. Spontaneously beating nodal-, atrial-, and ventricular-like cells were characterized based on the maximum rate of depolarization $(\mathrm{dV} / \mathrm{dt})$, action potential duration (APD) at 50 and $90 \%$ repolarization, and maximum diastolic potential. Recordings were conducted at physiological temperature $\left(37^{\circ} \mathrm{C}\right)$. The temperature of the recording chamber was controlled via a temperature control unit (TC 344B; Warner Instruments, Hamden, CT).

\section{Ratiometric $\mathrm{Ca}^{2+}$ microfluorometry}

Briefly, human iPSC-derived cardiomyocytes plated on coverslips were exposed to Fura-2-AM $(5 \mu \mathrm{M})$ for $30 \mathrm{~min}$ at room temperature, washed three times with extracellular bath solution, and given $30 \mathrm{~min}$ for de-esterification. For $\mathrm{Ca}^{2+}$ microfluorometry, the fluorophore was excited alternately with 340 and $380 \mathrm{~nm}$ wavelength illumination and images were acquired at $510 \mathrm{~nm}$ through a $20 \times$ objective. Recordings from each cell were obtained at a rate of $3 \mathrm{~Hz}$. After background subtraction, the fluorescence ratio $\mathrm{R}$ for individual cell was determined as the intensity of emission during $340 \mathrm{~nm}$ excitation $\left(\mathrm{I}_{340}\right)$ divided by $\mathrm{I}_{380}$, on a pixel-by-pixel basis. Activationinduced transients were generated by depolarization produced by microperfusion application of $50 \mathrm{mM} \mathrm{KCl} \mathrm{[22].}$

\section{Statistical analysis}

Data is presented as either mean $\pm \mathrm{SD}$ or as total percentage. Continuous variables were compared using the Student $t$ test, assuming equal variance and dichotomous variables were compared using the Fisher exact test. Mass spectrometry measurements between groups were compared for either the presence (assigned a number value of 1) or absence (assigned a number of value of 0 ) of the protein identified in the sample using non-parametric Wilcoxon rank-sum tests without adjusting for multiple 
testing. Mass spectrometry data analysis was performed by the biostatical consulting service at the Medical College of Wisconsin.

\section{Results}

\section{Clinical and echocardiographic characteristics of the discovery cohort}

As described in Table 1 the median age of the HFpEF subjects is slightly greater than the control subjects $(\mathrm{p}=0.04)$. The HFpEF group had a higher incidence of atrial fibrillation and cerebral vascular accident/transient ischemia in comparison to control subjects. Although not statistically significant, HFpEF subjects were more likely to have diabetes, coronary heart disease, hyperlipidemia and a distant smoking history. A significant number of HFpEF subjects were taking beta blockers compared to the control group. Echocardiogram studies confirmed the presence of diastolic dysfunction and increased LV pressure in the HFpEF group (Table 2). Left atrial volume indices were significantly elevated along with an increase in LV wall thickness in the HFpEF group compared to control.

\section{Overall description of proteomic findings}

Global proteomic experiments were performed using 21 separate platelet preparations. Combining these

\section{Table 1 Clinical characteristics of subjects}

\begin{tabular}{|c|c|c|c|}
\hline Characteristic & HFpEF $(n=9)$ & Control $(n=7)$ & $\mathrm{p}$ value $<0.05$ \\
\hline Age, years & $75 \pm 10$ & $62 \pm 13$ & 0.03 \\
\hline Women (\%) & 75 & 71 & n.s. \\
\hline Body mass index & $33 \pm 9$ & $33 \pm 10$ & n.s. \\
\hline Hypertensive (\%) & 67 & 75 & n.s. \\
\hline Hyperlipidemia (\%) & 67 & 63 & n.s. \\
\hline Diabetes (\%) & 56 & 25 & n.s. \\
\hline $\begin{array}{c}\text { Coronary artery } \\
\text { disease }(\%)\end{array}$ & 56 & 29 & n.s. \\
\hline h/o CVA/TIA (\%) & 50 & 0 & 0.02 \\
\hline h/o Afib (\%) & 78 & 0 & $<0.001$ \\
\hline Smoking history (\%) & 100 & 29 & $<0.001$ \\
\hline Current smoker (\%) & 11 & 14 & n.s. \\
\hline Former smoker (\%) & 89 & 14 & n.s. \\
\hline \multicolumn{4}{|l|}{ Medications } \\
\hline ACEI/ARB (\%) & 50 & 57 & n.s \\
\hline Beta-blocker (\%) & 100 & 50 & 0.009 \\
\hline $\begin{array}{l}\text { Aldosterone } \\
\text { antagonist (\%) }\end{array}$ & 0 & 0 & n.s. \\
\hline Statin (\%) & 75 & 57 & n.s. \\
\hline Diuretic (\%) & 44 & 43 & n.s. \\
\hline
\end{tabular}

h/o history of; CVA/TIA cerebral vascular accident/transient ischemic attack, Afib atrial fibrillation, $A C E I / A R B$ angiotensin converting enzyme inhibitor/angiotensin receptor blocker

The $\mathrm{p}$ value was calculated using two tailed student $\mathrm{t}$-tests for numerical variables and using Chi squared and Fisher's exact tests for categorical values
Table 2 Echocardiographic characteristics of subjects

\begin{tabular}{|c|c|c|c|}
\hline Characteristic & HFpEF $(n=9)$ & Control $(n=7)$ & p value $<0.05$ \\
\hline \multicolumn{4}{|l|}{ 2D Echocardiography } \\
\hline $\begin{array}{l}\text { LA volume index, } \\
\mathrm{ml} / \mathrm{m}^{2}\end{array}$ & $49 \pm 15$ & $32 \pm 7.7$ & 0.018 \\
\hline $\begin{array}{l}\text { LV internal diameter, } \\
\mathrm{cm}\end{array}$ & $4.64 \pm 0.37$ & $4.73 \pm 0.08$ & NS \\
\hline $\begin{array}{l}\text { Interventricular sep- } \\
\text { tum, cm }\end{array}$ & $1.25 \pm 0.12$ & $0.92 \pm 0.01$ & 0.001 \\
\hline Posterior wall, $\mathrm{cm}$ & $1.20 \pm 0.18$ & $0.88 \pm 0.09$ & 0.004 \\
\hline LV mass index, $\mathrm{g} / \mathrm{m}^{2}$ & $112 \pm 20$ & $90 \pm 45$ & NS \\
\hline Ejection fraction, \% & $55 \pm 6$ & $60 \pm 3$ & NS \\
\hline \multicolumn{4}{|l|}{ Doppler data } \\
\hline E peak, $\mathrm{cm} / \mathrm{s}$ & $86.6 \pm 26$ & $68.0 \pm 5.8$ & NS \\
\hline $\mathrm{e}^{\prime}$ peak & $6.9 \pm 1.66$ & $7.7 \pm 1.03$ & NS \\
\hline E/e' ratio & $14.4 \pm 5.13$ & $9.28 \pm 0.37$ & NS \\
\hline $\begin{array}{l}\text { Diastolic } \\
\quad \text { dysfunction, \% }\end{array}$ & 100 & 14 & $<0.001$ \\
\hline
\end{tabular}

$L A$ left atrium, $L V$ left ventricle

The $\mathrm{p}$ value was calculated using two-tailed student $\mathrm{t}$-tests

experiments, a total of 6102 proteins were identified with at least five scans with a protein probability of $>0.85$. The HFpEF hospitalized group had a total of 5546 proteins, the HFpEF outpatient group had a total of 4854 proteins and the control group had a total of 5498 proteins identified. A total of 4172 proteins were found to be shared among all three groups. When comparing two groups, 321 proteins were identified as being shared amongst the outpatient and control group. A total of 361 proteins were found in both the hospitalized and outpatient groups and a total of 848 proteins were found in both the control and hospitalized groups. The number of unique proteins in each group consisted of 165 proteins in the HFpEF hospitalized group, 78 proteins in the HFpEF outpatient group, and 157 unique proteins in the control group (Fig. 1). To assess for possible contamination from other blood cells, the data set was scanned for the presence of CD45 and MHC II chains; proteins that are expressed in leukocytes. These proteins were not found in the data set; therefore, the contamination from leukocytes was likely to be minimal. However, complement C5 and $\beta$-2-glycoprotein were identified in the data sets denoting some serum contamination was present.

\section{Unique proteins in each study group}

The platelet proteome from nine subjects were analyzed in the HFpEF hospitalized group, five subjects in the HFpEF outpatient and seven subjects in the control group. The unique proteins identified with a scan count of $>9$ are listed in Table 3 . In addition after applying the non-parametric Wilcoxon rank-sum test, 37 proteins 


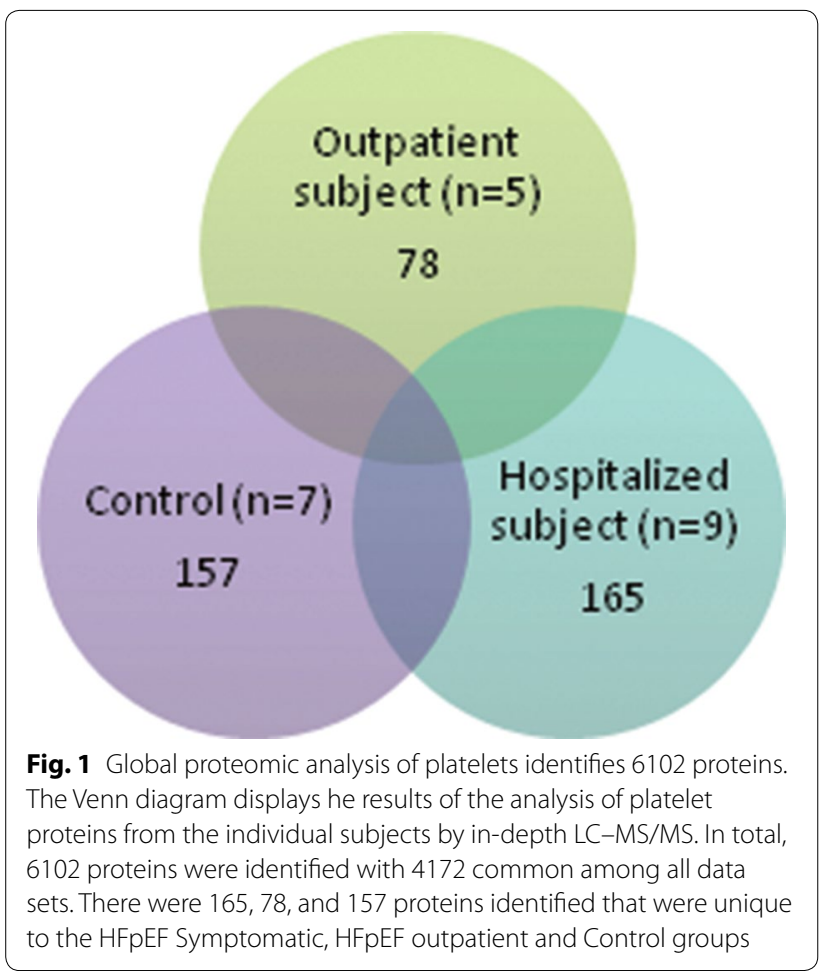

were found to be more prevalent amongst the combined HFpEF groups than with the control and 77 proteins were identified that were found to be more prevalent amongst the control with a p value $<0.05$. These proteins are listed Table 4.

\section{Discovery and validation cohort ELISA confirmation}

One particularly interesting finding was the identification of S100A8. The $\mathrm{m} / \mathrm{z}$ ratio graph representing S100A8 is shown in Fig. 2. Even though the p value was 0.08 , it was identified in six out of the nine HFpEF subjects. S100A8 has not been previously associated with HFpEF but has been linked to advanced heart failure [23]. Additionally, S100A8 has been found to correlate with traditional cardiovascular risk factors and the manifestation of cardiovascular disease $[24,25]$. For these reasons, we decided to look more closely at S100A8 to verify its association with HFpEF. S100A8 is found in platelets $[26,27]$ and the plasma [25, 28]; because we used the platelet lysates for the mass spect analysis, we used the plasma samples for quantitative ELISA analysis. Figure 3 shows that plasma S100A8 levels are increased symptomatic HFpEF when compared to control (MCW cohort). We then validated these findings by studying a larger cohort of subjects recruited from the Northwestern University HFpEF Program. In this larger cohort, we saw a similar increase in plasma S100A8 levels in the HFpEF group (Fig. 3; Northwestern cohort).

\section{Exogenously applied rS100A8 affects cardiomyocyte function in vitro}

To ascertain whether S100A8 may play a causal role in the HFpEF disease process; we developed a bedside-tobench translational system (Fig. 4) to screen for biological effects of identified proteins on cardiomyocyte function in vitro. We added recombinant S100A8 $(800 \mathrm{ng} / \mathrm{ml})$ to iPSC-derived cardiomyocytes in vitro and measured action potentials and intracellular $\mathrm{Ca}^{2+}$ concentrations separately. This specific concentration of rS100A8 was selected as it was the average plasma concentration observed in the HFpEF group (Fig. 3).

Action potentials (APs) were recorded in the current clamp mode using the patch clamp technique. The recordings were acquired from spontaneously beating cells. External application of rS100A8 slowed the spontaneous pacing within $25 \mathrm{~s}$ which suggests the interaction with a membrane receptor. In the example shown in Fig. 5a, the spontaneous generation of APs with atrial-like properties was slowed in the presence of rS100A8. The peak-to-peak AP interval increased from 1.5 to $2.4 \mathrm{~s}$. This effect was reversible upon washout of rS100A8 (results not shown). In a different beating cell cluster, the recorded atrial-like APs showed arrhythmogenic tendencies characterized by infrequent incidents of failed triggering of APs, as shown in Fig. 5b. The rS100A8 exacerbated this trend by increasing the frequency of these failed events. Thus, the electrophysiological profile of these iPSC-derived cardiomyocytes is profoundly impacted by rS100A8.

Intracellular $\mathrm{Ca}^{2+}$ concentrations $\left(\left[\mathrm{Ca}^{2+}\right]_{\mathrm{i}}\right)$ were measured using the ratiometric $\mathrm{Ca}^{2+}$ microfluorometry technique with Fura-2-AM fluorescent dye. The $\left[\mathrm{Ca}^{2+}\right]_{i}$ were monitored in spontaneously beating cells. The sample trace (Fig. 5c) shows a spontaneous $\mathrm{Ca}^{2+}$ transient recording that was interrupted by activity-induced depolarization $\left(50 \mathrm{mM} \mathrm{K}^{+}\right.$; duration of application as noted) at certain time points (indicated by the red arrows) using a microperfusion system. Of particular note is the recovery of the spontaneous $\mathrm{Ca}^{2+}$ transient following each depolarizing pulse. In the absence of $\mathrm{rS100A8}$, the recovery was relatively fast. In contrast, the recovery was considerably slower in the presence of rS100A8. Following a third depolarizing pulse, recovery was not evident until the washout of rS100A8; this observation also suggests that $\mathrm{rS100A8}$ effects are mediated through a membrane receptor. In summary, rS100A8 adversely affected the calcium handling of iPSC-derived cardiomyocytes.

\section{Conclusions}

The key finding of this study was that it was possible to derive platelet protein data sets specific for HFpEF patients. These proof-of-concept findings suggest that 
Table 3 List of unique proteins identified in each group with $>9$ scans total

\begin{tabular}{|c|c|c|}
\hline Protein & Accession & Description \\
\hline \multicolumn{3}{|c|}{ Present only in HFpEF symptomatic group } \\
\hline NALP2 & Q9NX02 & NACHT, LRR and PYD domains-containing protein \\
\hline ZEP3 & Q5T1R4 & Transcription factor HIVEP3 \\
\hline MET25 & Q8N6Q8 & Methyltransferase-like protein 25 \\
\hline SCAF8 & Q9UPN6 & Protein SCAF8 \\
\hline CC105 & Q8IYK2 & Coiled-coil domain-containing protein 105 \\
\hline FILA & P20930 & Filaggrin \\
\hline MEG11 & A6BM72 & Multiple epidermal growth factor-like domains protein 11 \\
\hline F19A2 & Q8N3H0 & Protein FAM19A2 \\
\hline GRM1 & Q13255 & Metabotropic glutamate receptor \\
\hline YP010 & Q96M66 & Putative uncharacterized protein FLJ32790 \\
\hline PSMD4 & P55036 & $26 \mathrm{~S}$ proteasome non-ATPase regulatory subunit 4 \\
\hline PCCA & P05165 & Propionyl-CoA carboxylase alpha chain, mitochondrial \\
\hline TCPR2 & 015040 & Tectonin beta-propeller repeat-containing protein \\
\hline KPRP & Q5T749 & Keratinocyte proline-rich protein \\
\hline GTPB5 & Q9H4K7 & GTP-binding protein 5 \\
\hline CV031 & 095567 & Uncharacterized protein C22orf31 \\
\hline TFB2 M & Q9H5Q4 & Dimethyladenosine transferase 2 , mitochondrial \\
\hline SPXN4 & Q5MJ08 & Sperm protein associated with the nucleus on the X chromosome N4 \\
\hline PF21A & Q96BD5 & PHD finger protein $21 \mathrm{~A}$ \\
\hline \multicolumn{3}{|c|}{ Present only in HFpEF asymptomatic group } \\
\hline $\mathrm{H} 2 \mathrm{~A} 1 \mathrm{H}$ & Q96KK5 & Histone $\mathrm{H} 2 \mathrm{~A}$ type \\
\hline $\mathrm{H} 2 \mathrm{~A} 3$ & Q7L7L0 & Histone H2A type 3 \\
\hline POK7 & Q9QC07 & HERV-K_1q23.3 provirus ancestral Pol protein \\
\hline $\mathrm{CC} 127$ & Q96BQ5 & Coiled-coil domain-containing protein 127 \\
\hline CC85C & A6NKD9 & Coiled-coil domain-containing protein $85 \mathrm{C}$ \\
\hline WDR75 & Q8IWA0 & WD repeat-containing protein 75 \\
\hline CXCL3 & P19876 & C-X-C motif chemokine 3 \\
\hline RGPS1 & Q5JS13 & Ras-specific guanine nucleotide-releasing factor RalGPS1 \\
\hline CXCL2 & P19875 & C-X-C motif chemokine 2 \\
\hline CHMP7 & Q8WUX9 & Charged multivesicular body protein 7 \\
\hline CK2N2 & Q96S95 & Calcium/calmodulin-dependent protein kinase II inhibitor 2 \\
\hline $\mathrm{CHIT1}$ & Q13231 & Chitotriosidase-1 \\
\hline NOX1 & Q9Y5S8 & NADPH oxidase 1 \\
\hline RBY1C & P0DJD4 & RNA-binding motif protein, $Y$ chromosome, family 1 member $C$ \\
\hline WFDC3 & Q8IUB2 & WAP four-disulfide core domain protein 3 \\
\hline$A B C B B$ & O95342 & Bile salt export pump \\
\hline HHAT & Q5VTY9 & Protein-cysteine N-palmitoyltransferase HHAT \\
\hline MID51 & Q9NQG6 & Mitochondrial dynamic protein MID51 \\
\hline LMNB1 & P20700 & Lamin-B1 \\
\hline \multicolumn{3}{|c|}{ Present only in control group } \\
\hline MY15B & Q96JP2 & Putative unconventional myosin-XVB \\
\hline $\mathrm{CCO} 20$ & Q8ND61 & Uncharacterized protein C3orf20 \\
\hline MCTS1 & Q9ULC4 & Malignant T cell-amplified sequence 1 \\
\hline KSR1 & Q8IVT5 & Kinase suppressor of Ras 1 \\
\hline PRP6 & O94906 & Pre-mRNA-processing factor 6 \\
\hline DDX59 & Q5T1V6 & Probable ATP-dependent RNA helicase DDX59 \\
\hline AL1A3 & P47895 & Aldehyde dehydrogenase family 1 member A3 \\
\hline PCCB & P05166 & Propionyl-CoA carboxylase beta chain, mitochondrial \\
\hline
\end{tabular}


Table 3 continued

\begin{tabular}{|c|c|c|}
\hline Protein & Accession & Description \\
\hline HNRCL & O60812 & Heterogeneous nuclear ribonucleoprotein C-like 1 \\
\hline $\mathrm{BIRC} 3$ & Q13489 & Baculoviral IAP repeat-containing protein 3 \\
\hline NDUF4 & Q9P032 & NADH dehydrogenase 1 alpha subcomplex assembly factor 4 \\
\hline $\mathrm{MIRO} 2$ & Q8IXI1 & Mitochondrial Rho GTPase 2 \\
\hline \multicolumn{3}{|c|}{ Present in HFpEF symptomatic and HFpEF asymptomatic groups but not control group } \\
\hline MBD5 & Q9P267 & Methyl-CpG-binding domain protein 5 \\
\hline RRBP1 & Q9P2E9 & Ribosome-binding protein 1 \\
\hline ZNF79 & Q15937 & Zinc finger protein 79 \\
\hline DCNL5 & Q9BTE7 & DCN1-like protein 5 \\
\hline RGS3 & P49796 & Regulator of G-protein signaling 3 \\
\hline TMOD2 & Q9NZR1 & Tropomodulin-2 \\
\hline MYO5B & Q9ULV0 & Unconventional myosin-Vb \\
\hline SC24D & O94855 & Protein transport protein Sec24D \\
\hline SHIP1 & Q92835 & Phosphatidylinositol 3,4,5-trisphosphate 5-phosphatase 1 \\
\hline ASIC1 & P78348 & Acid-sensing ion channel 1 \\
\hline DMXL1 & Q9Y485 & DmX-like protein 1 \\
\hline RECQ1 & P46063 & ATP-dependent DNA helicase Q1 \\
\hline LY10L & Q9H930 & Nuclear body protein SP140-like protein \\
\hline MBNL1 & Q9NR56 & Muscleblind-like protein 1 \\
\hline KCC2B & Q13554 & Calcium/calmodulin-dependent protein kinase type II subunit beta \\
\hline LIPA3 & O75145 & Liprin-alpha-3 \\
\hline CD109 & Q6YHK3 & CD109 antigen \\
\hline ZN141 & Q15928 & Zinc finger protein 141 \\
\hline YTHD2 & Q9Y5A9 & YTH domain family protein 2 \\
\hline PLCD & Q9NRZ5 & 1-acyl-sn-glycerol-3-phosphate acyltransferase delta \\
\hline KIFA3 & Q92845 & Kinesin-associated protein 3 \\
\hline TRI25 & Q14258 & E3 ubiquitin/ISG15 ligase TRIM25 \\
\hline ETUD1 & Q7Z2Z2 & Elongation factor Tu GTP-binding domain-containing protein 1 \\
\hline CDN1B & P46527 & Cyclin-dependent kinase inhibitor 1B \\
\hline CO4A4 & P53420 & Collagen alpha-4(IV) chain \\
\hline TEX35 & Q5T0J7 & Testis-expressed sequence 35 protein \\
\hline MUC16 & Q8WXI7 & Mucin-16 \\
\hline NPIL2 & A6NJ64 & NPIP-like protein LOC729978 \\
\hline IRF2 & P14316 & Interferon regulatory factor 2 \\
\hline MK07 & Q13164 & Mitogen-activated protein kinase 7 \\
\hline APOA & P08519 & Apolipoprotein(a) \\
\hline $\mathrm{HIBCH}$ & Q6NVY1 & 3-hydroxyisobutyryl-CoA hydrolase, mitochondrial \\
\hline USH1C & Q9Y6N9 & Harmonin \\
\hline GOG8O & A6NCC3 & Golgin subfamily A member 80 \\
\hline NADE & Q6IA69 & Glutamine-dependent NAD(+) synthetase \\
\hline MET17 & $\mathrm{Q} 9 \mathrm{H} 7 \mathrm{HO}$ & Methyltransferase-like protein 17 , mitochondrial \\
\hline PITH1 & Q9GZP4 & PITH domain-containing protein 1 \\
\hline |L1R1 & P14778 & Interleukin-1 receptor type 1 \\
\hline C1GLT & Q9NS00 & Glycoprotein-N-acetylgalactosamine 3-beta-galactosyltransferase 1 \\
\hline OR2L3 & Q8NG85 & Olfactory receptor $2 \mathrm{~L} 3$ \\
\hline KV122 & P04430 & Ig kappa chain V-I region BAN \\
\hline GG8L2 & A6NP81 & Golgin subfamily A member 8-like protein 2 \\
\hline ZFYV1 & Q9HBF4 & Zinc finger FYVE domain-containing protein 1 \\
\hline CJ076 & Q5T2E6 & UPF0668 protein C10orf76 \\
\hline
\end{tabular}


Table 3 continued

\begin{tabular}{|c|c|c|}
\hline Protein & Accession & Description \\
\hline STAB 1 & Q9NY15 & Stabilin-1 \\
\hline EHBP1 & Q8NDI1 & EH domain-binding protein 1 \\
\hline ANR24 & Q8TF21 & Ankyrin repeat domain-containing protein 24 \\
\hline FAHD1 & Q6P587 & Acylpyruvase FAHD1, mitochondrial \\
\hline IWS1 & Q96ST2 & Protein IWS1 homolog \\
\hline THAP2 & Q9H0W7 & THAP domain-containing protein 2 \\
\hline FNIP1 & Q8TF40 & Folliculin-interacting protein 1 \\
\hline STK16 & 075716 & Serine/threonine-protein kinase 16 \\
\hline CXX1 & 015255 & CAAX box protein 1 \\
\hline GOG8R & 16L899 & Golgin subfamily A member 8R \\
\hline SRRT & Q9BXP5 & Serrate RNA effector molecule homolog \\
\hline ZN611 & Q8N823 & Zinc finger protein 611 \\
\hline MRE11 & P49959 & Double-strand break repair protein MRE11A \\
\hline LONM & P36776 & Lon protease homolog, mitochondrial \\
\hline GOG8 N & F8WBI6 & Golgin subfamily A member $8 \mathrm{~N}$ \\
\hline ALPK2 & Q86TB3 & Alpha-protein kinase 2 \\
\hline $\mathrm{E} \mid 2 \mathrm{BG}$ & Q9NR50 & Translation initiation factor elF-2B subunit gamma \\
\hline NBPFL & A6NDD8 & Neuroblastoma breakpoint family member 21 \\
\hline ETV7 & Q9Y603 & Transcription factor ETV7 \\
\hline
\end{tabular}

the platelet proteome might provide a useful tool for screening for HFpEF-associated biomarkers. Although several platelet proteins were identified in HFpEF subjects; their exact connection to HFpEF has yet to be determined. Though our data is limited by the small size, our discovery cohort has similar characteristics of larger HFpEF cohorts reported in the literature [29-31]. By combining proteomics with bioactivity assays, we have demonstrated that the platelet proteome is an untapped resource for determining disease mediators in HFpEF.

The platelet proteome in healthy individuals is remarkably stable with only minor differences in protein expression patterns [32]. Veitinger et al. suggests the difference in platelet proteins between individuals is a results of the uptake of plasma proteins by the platelet [33]. Inflammation is closely linked with HFpEF [34] and considering that platelets are involved in the inflammatory process, it is not surprising that our proteomics screen led to the identification of several proteins also involved in inflammation. These include serum amyloid A (SAA), Lipopolysaccharide binding protein, apolipoprotein A1 and S100A8. Two proteins, serum amyloid-A (SAA) protein 1 and apolipoprotein A1 were increased in the sera of non-human primates after druginduced cardiac injury [35]. In addition, increased levels of SAA in serum have been associated with coronary heart disease [36], as well as systolic heart failure [37] and has been shown to be a predictor of cardiovascular outcomes in women [38].
S100A8 is a member of the S100 calcium-binding family of proteins, which exhibit increased levels in a number of inflammatory states. S100A8 is commonly mentioned with its binding partner, S100A9. Even though S100A8 is found in the plasma [23], it is known that platelets and megakaryocytes might serve as an additional source of S100A8 and might contribute to the plasma pool of S100A8/A9 in inflammatory diseases and cardiovascular events [26, 27, 39].

S100A8 and S100A9 are not normally expressed in cardiomyocytes [40] although its cardiac expression can be induced by endotoxins or angiotensin II [40, 41]. Release of S100A8/A9 from cells allows it to act in a paracrine or autocrine fashion. These extracellular functions are mediated by the toll-like receptor 4 (TLR4) $[42,43]$ or the receptor for advanced glycation end products (RAGE) $[40,44,45]$. More recently, CD36 has been identified as a receptor [26]. In the mouse, S100A8/A9 signals through RAGE to promote inflammation and fibrosis after angiotensin II or hypoxic-induced cardiac injury [41, 45].

Increased platelet S100A8 mRNA and plasma protein levels were present in patients with acute myocardial infarction [39]. Plasma levels of S100A8/A9 predicted risk of future myocardial infarction, stroke or death in post-menopausal healthy women [25]. Elevated S100A8 levels have also been found in other inflammatory disorders which are associated with abnormalities of vascular and cardiac function, particularly diastolic dysfunction, such as diabetes [46-48], end-stage renal disease [49, 
Table 4 Proteins preferential to either HFpEF or control groups

\begin{tabular}{|c|c|c|c|}
\hline Protein & Accession & Description & $\mathrm{p}$ value \\
\hline \multicolumn{4}{|c|}{ Proteins preferentially found in HFpEF group } \\
\hline SAA2 & PODJI9 & Serum amyloid $A-2$ protein & 0.0019 \\
\hline SAA1 & PODJI8 & Serum amyloid A-1 protein & 0.0019 \\
\hline PHF3 & Q92576 & PHD finger protein 3 & 0.0090 \\
\hline RGPD5 & Q99666 & RANBP2-like and GRIP domain-containing protein 5/6 & 0.0123 \\
\hline RGPD8 & 014715 & RANBP2-like and GRIP domain-containing protein 8 & 0.0124 \\
\hline YMEL1 & Q96TA2 & ATP-dependent zinc metalloprotease YME1L1 & 0.0256 \\
\hline FHR2 & P36980 & Complement factor H-related protein 2 & 0.0269 \\
\hline RGPD3 & A6NKT7 & RanBP2-like and GRIP domain-containing protein 3 & 0.0278 \\
\hline CG010 & Q9HAC7 & CaiB/baiF CoA-transferase family protein C7orf10 & 0.0279 \\
\hline RRBP1 & Q9P2E9 & Ribosome-binding protein 1 & 0.0279 \\
\hline ZNF79 & Q15937 & Zinc finger protein 79 & 0.0279 \\
\hline DCNL5 & Q9BTE7 & DCN1-like protein 5 & 0.0279 \\
\hline RECQ1 & P46063 & ATP-dependent DNA helicase Q1 & 0.0283 \\
\hline PERQ2 & Q6Y7W6 & PERQ amino acid-rich with GYF domain-containing protein 2 & 0.0285 \\
\hline MBD5 & Q9P267 & Methyl-CpG-binding domain protein 5 & 0.0286 \\
\hline GPCP1 & Q9NPB8 & Glycerophosphocholine phosphodiesterase GPCPD1 & 0.0286 \\
\hline NOL10 & Q9BSC4 & Nucleolar protein 10 & 0.0351 \\
\hline LBP & P18428 & Lipopolysaccharide-binding protein & 0.0432 \\
\hline AFF1 & P51825 & AF4/FMR2 family member 1 & 0.0442 \\
\hline SOX30 & O94993 & Transcription factor SOX-30 & 0.0458 \\
\hline DCP1A & Q9NPI6 & mRNA-decapping enzyme $1 \mathrm{~A}$ & 0.0465 \\
\hline AN20B & Q5CZ79 & Ankyrin repeat domain-containing protein $20 \mathrm{~B}$ & 0.0468 \\
\hline TCOF & Q13428 & Treacle protein & 0.0479 \\
\hline MEN1 & 000255 & Menin & 0.0486 \\
\hline S10A8 & P05109 & S100A8 & 0.0808 \\
\hline \multicolumn{4}{|c|}{ Proteins preferentially found in control group } \\
\hline MY15B & Q96JP2 & Putative unconventional myosin-XVB & 0.0012 \\
\hline ASXL3 & Q9C0F0 & Putative Polycomb group protein ASXL3 & 0.0045 \\
\hline CCO20 & Q9NX02 & NACHT, LRR and PYD domains-containing protein 2 & 0.0045 \\
\hline TEKT1 & Q969V4 & Tektin-1 & 0.0070 \\
\hline SEP10 & Q9P0V9 & Septin-10 OS $=$ Homo sapiens & 0.0103 \\
\hline LMNB2 & Q03252 & Lamin-B2 OS = Homo sapiens & 0.0103 \\
\hline ZN469 & Q96JG9 & Zinc finger protein 469 & 0.0146 \\
\hline PARI & Q9NWS1 & PCNA-interacting partner & 0.0148 \\
\hline NOP2 & P46087 & Putative ribosomal RNA methyltransferase NOP2 & 0.0148 \\
\hline FIGL2 & A6NMB9 & Putative fidgetin-like protein 2 & 0.0148 \\
\hline MCTS1 & Q9ULC4 & Malignant T-cell-amplified sequence 1 & 0.0148 \\
\hline TANC2 & Q9HCD6 & Protein TANC2 & 0.0148 \\
\hline HEMO & P22557 & 5-aminolevulinate synthase, erythroid-specific, mitochondrial & 0.0148 \\
\hline PRP6 & O94906 & Pre-mRNA-processing factor 6 & 0.0148 \\
\hline TACC2 & O95359 & Transforming acidic coiled-coil-containing protein 2 & 0.0200 \\
\hline SMC3 & Q9UQE7 & Structural maintenance of chromosomes protein 3 & 0.0261 \\
\hline GTF2I & P78347 & General transcription factor II-I & 0.0262 \\
\hline $\mathrm{Cl} 1084$ & Q5VXU9 & Uncharacterized protein & 0.0268 \\
\hline CCS & 014618 & Copper chaperone for superoxide dismutase & 0.0294 \\
\hline cox6C & P09669 & Cytochrome c oxidase subunit $6 \mathrm{C}$ & 0.0324 \\
\hline INT11 & Q5TA45 & Integrator complex subunit 11 & 0.0352 \\
\hline DCLK1 & 015075 & Serine/threonine-protein kinase DCLK1 & 0.0363 \\
\hline
\end{tabular}


Table 4 continued

\begin{tabular}{|c|c|c|c|}
\hline Protein & Accession & Description & $p$ value \\
\hline SSH1 & Q8WYL5 & Protein phosphatase Slingshot homolog 1 & 0.0380 \\
\hline PJA1 & Q8NG27 & E3 ubiquitin-protein ligase Praja-1 & 0.0390 \\
\hline BRK1 & Q8WUW1 & Protein BRICK1 & 0.0422 \\
\hline UBP44 & Q9H0E7 & Ubiquitin carboxyl-terminal hydrolase 44 & 0.0422 \\
\hline PLCG2 & P16885 & 1-phosphatidylinositol 4,5-bisphosphate phosphodiesterase gamma-2 & 0.0428 \\
\hline IGS22 & Q8N9C0 & Immunoglobulin superfamily member 22 & 0.0431 \\
\hline RPGFL & Q9UHV5 & Rap guanine nucleotide exchange factor-like 1 & 0.0431 \\
\hline CN070 & Q86TU6 & Putative uncharacterized protein encoded by LINC00523 & 0.0431 \\
\hline TRI35 & Q9UPQ4 & Tripartite motif-containing protein 35 & 0.0431 \\
\hline TOPB1 & Q92547 & DNA topoisomerase 2-binding protein 1 & 0.0431 \\
\hline R3HD4 & Q96D70 & R3H domain-containing protein 4 & 0.0431 \\
\hline ABR & Q12979 & Active breakpoint cluster region-related protein & 0.0431 \\
\hline ZN441 & Q8N8Z8 & Zinc finger protein 441 & 0.0431 \\
\hline ZN451 & Q9Y4E5 & Zinc finger protein 451 & 0.0431 \\
\hline DCE2 & Q05329 & Glutamate decarboxylase 2 & 0.0431 \\
\hline RAB31 & Q13636 & Ras-related protein Rab-31 & 0.0431 \\
\hline PDE3A & Q14432 & cGMP-inhibited 3', 5'-cyclic phosphodiesterase A & 0.0431 \\
\hline TRPM2 & O94759 & Transient receptor potential channel subfamily M member 2 & 0.0431 \\
\hline C163B & Q9NR16 & Scavenger receptor cysteine-rich type 1 protein M160 & 0.0431 \\
\hline CA094 & Q6P1W5 & Uncharacterized protein C1 orf94 & 0.0431 \\
\hline RSBN1 & Q5VWQ0 & Round spermatid basic protein 1 & 0.0431 \\
\hline GRM8 & 000222 & Metabotropic glutamate receptor 8 & 0.0431 \\
\hline KLHL7 & Q8IXQ5 & Kelch-like protein 7 & 0.0431 \\
\hline SHAN3 & Q9BYB0 & SH3 and multiple ankyrin repeat domains protein 3 & 0.0431 \\
\hline TTI1 & 043156 & TELO2-interacting protein 1 homolog & 0.0431 \\
\hline FMO4 & P31512 & Dimethylaniline monooxygenase [N-oxide-forming] 4 & 0.0431 \\
\hline RARB & P10826 & Retinoic acid receptor beta & 0.0431 \\
\hline UTY & 014607 & Histone demethylase UTY & 0.0431 \\
\hline SLK & Q9H2G2 & STE20-like serine/threonine-protein kinase & 0.0431 \\
\hline RB39B & Q96DA2 & Ras-related protein Rab-39B & 0.0435 \\
\hline RB43L & A6NDJ8 & Putative Rab-43-like protein & 0.0435 \\
\hline RAB4B & P61018 & Ras-related protein Rab- $4 \mathrm{~B}$ & 0.0435 \\
\hline RAB12 & Q61Q22 & Ras-related protein Rab-12 & 0.0435 \\
\hline RAB43 & Q86YS6 & Ras-related protein Rab-43 & 0.0435 \\
\hline RAB30 & Q15771 & Ras-related protein Rab-30 & 0.0435 \\
\hline GRM7 & Q14831 & Metabotropic glutamate receptor 7 & 0.0435 \\
\hline ZNF67 & Q15940 & Putative zinc finger protein 726P1 & 0.0435 \\
\hline FAKD5 & Q7L8L6 & FAST kinase domain-containing protein 5 & 0.0435 \\
\hline ZNF98 & A6NK75 & Zinc finger protein 98 & 0.0435 \\
\hline MFSD9 & Q8NBP5 & Major facilitator superfamily domain-containing protein 9 & 0.0435 \\
\hline RECK & 095980 & Reversion-inducing cysteine-rich protein with Kazal motifs & 0.0435 \\
\hline AL1A3 & P47895 & Aldehyde dehydrogenase family 1 member A3 & 0.0435 \\
\hline VP37C & A5D8V6 & Vacuolar protein sorting-associated protein $37 \mathrm{C}$ & 0.0435 \\
\hline ZN492 & Q9P255 & Zinc finger protein 492 & 0.0435 \\
\hline VPS29 & Q9UBQ0 & Vacuolar protein sorting-associated protein 29 & 0.0435 \\
\hline HNRCL & 060812 & Heterogeneous nuclear ribonucleoprotein C-like 1 & 0.0435 \\
\hline DHRS7 & Q9Y394 & Dehydrogenase/reductase SDR family member 7 & 0.0452 \\
\hline BRD8 & Q9H0E9 & Bromodomain-containing protein 8 & 0.0455 \\
\hline IF2P & 060841 & Eukaryotic translation initiation factor 5B & 0.0455 \\
\hline
\end{tabular}


Table 4 continued

\begin{tabular}{llll}
\hline Protein & Accession & Description & p value \\
\hline GDPD3 & Q7L5L3 & Glycerophosphodiesterase domain-containing protein 3 & 0.0456 \\
SYSC & P49591 & Serine-tRNA ligase, cytoplasmic & 0.0465 \\
NEK9 & Q8TD19 & Serine/threonine-protein kinase Nek9 & 0.0473 \\
\hline
\end{tabular}

$\mathrm{p}$ values are calculated based on the non-parametric Wilcoxon rank-sum tests

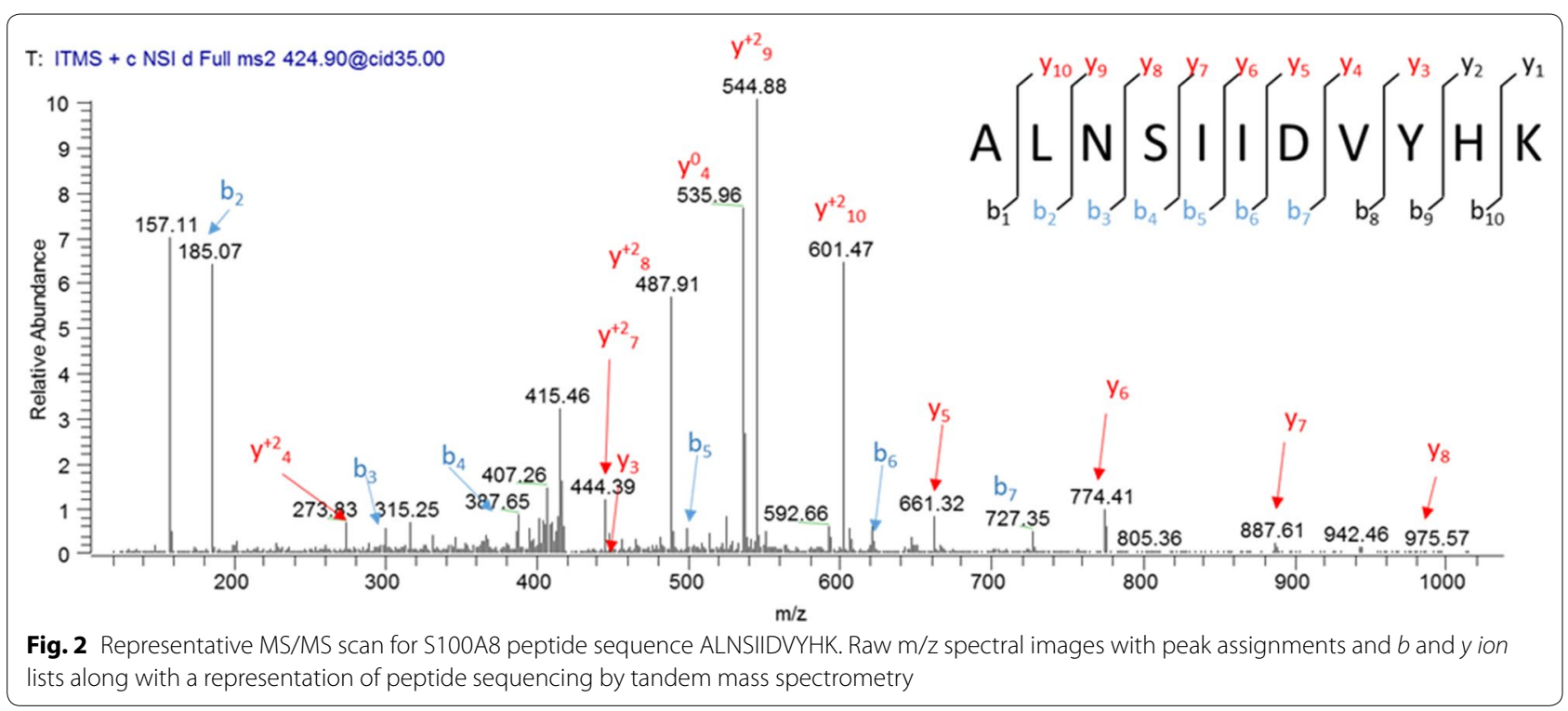

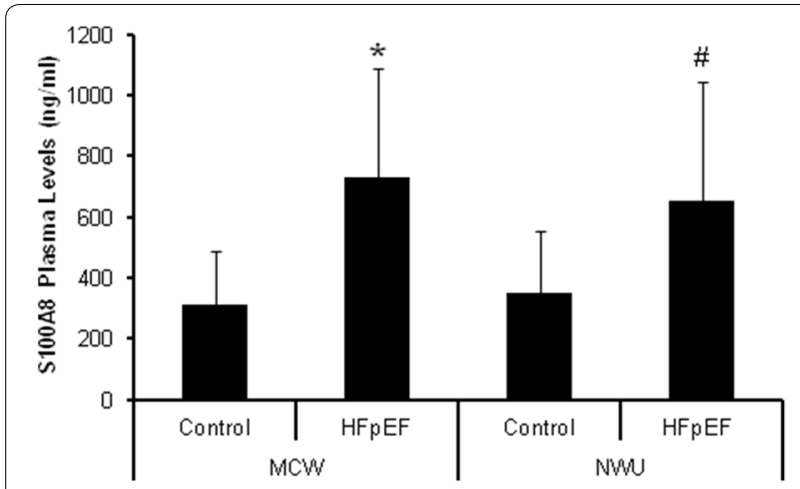

Fig. 3 Plasma levels of S100A8 in control vs. HFpEF groups. a S100A8 is found in increased levels in the plasma of subjects with HFpEF vs. control subjects as detected by ELISA. The MCW columns include the control $(n=7)$ and HFpEF $(n=9)$ from the discovery cohort and the NWU colums include the control $(n=18)$ and HFpEF $(n=25)$ samples from the validation cohort. ${ }^{*} p<0.006$ vs MCW Control. ${ }^{*} p<0$. 002 vs NWU Control

$50]$, and inflammatory bowel disease $[51,52]$. This is the first association of S100A8 with HFpEF, yet its role in the disease process still needs be elucidated. S100A8 has immediate effects on the electrophysiological and $\mathrm{Ca}^{2+}$ handling profiles of human induced cardiomyocytes suggesting that S100A8 is acting through a membrane receptor. S100A8 interaction with RAGE affects calcium flux in neonatal rat ventricular cardiomyocytes and HL-1 cardiomyocytes $[40,53]$. The adverse effects on the electrophysiological and $\mathrm{Ca}^{2+}$ handling profiles resulting from S100A8 treatment of human induced cardiomyocytes; validates our bedside-to-bench translational screen as an approach to identify bioactive proteins that may contribute to the disease mechanisms in HFpEF.

We also considered the possibility that subjects progress to HFpEF through loss of cardioprotective proteins. Therefore, we searched amongst our control group and were able to identify four proteins that could potentially have protective qualities against the development of heart failure. Cyclic nucleotide phosphodiesterase 3A1 (PDE3A) regulates $\beta$-adrenergic signaling to effect physiological cardiac performance. Furthermore, PDE3A protects the heart against angiotensin II-induced cardiac remodeling in mice [54]. Copper Chaperone for Superoxide Dismutase (CCS) plays a role in copper delivery to tissues; disturbances in copper homeostasis mediates cardiomyopathy [55]. Zinc finger protein 451 a negative regulator of TGF-beta signaling [56]. The transient receptor potential cation channel subfamily $M$ member 2 


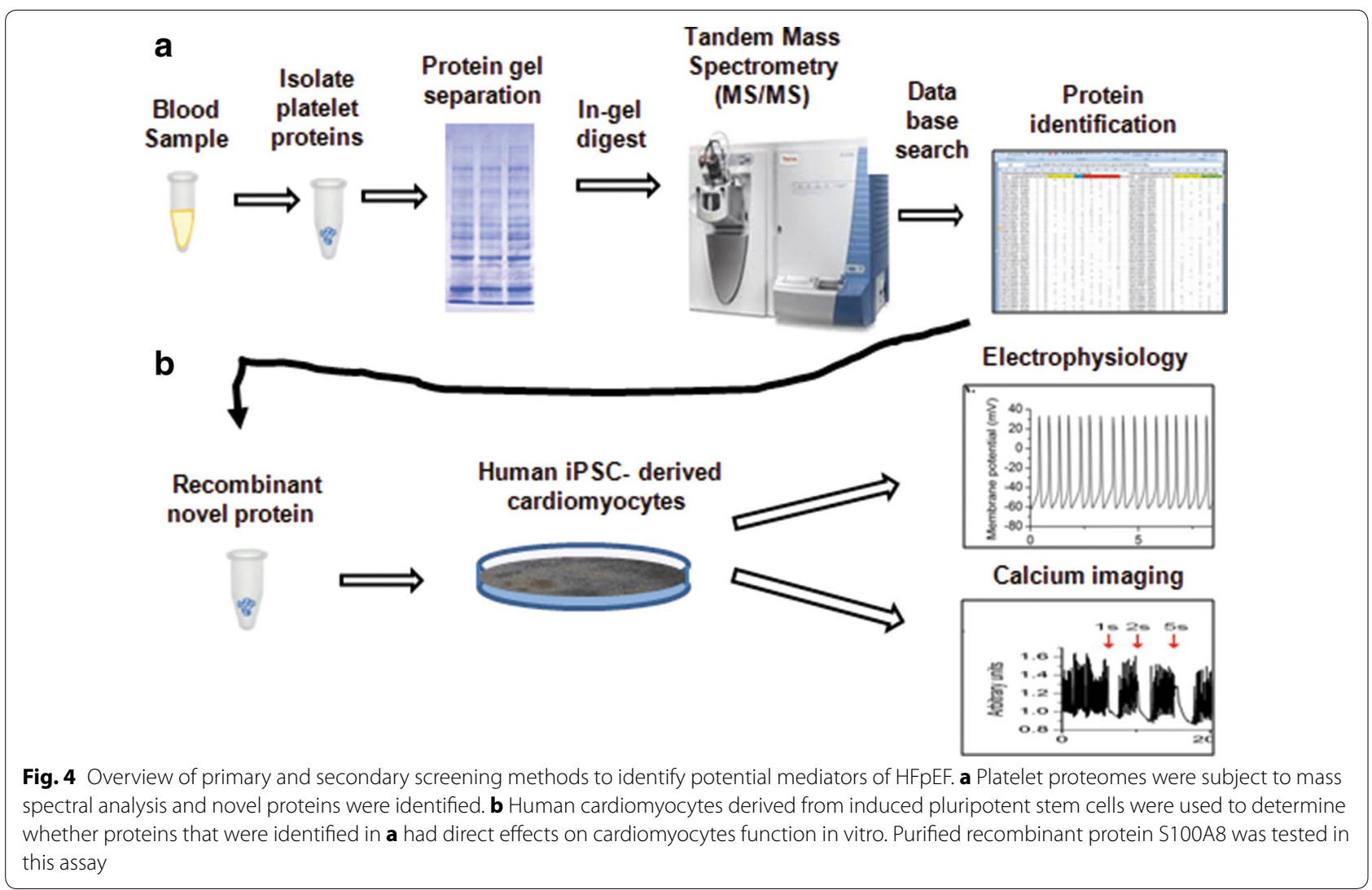

(TRPM2) protein limits oxidative stress injury and dampens the inflammatory response [57].

The present study must be interpreted within the context of its limitations. First of all, this was a discovery effort and not designed as a quantitative proteomic analysis. Therefore, we cannot determine if specific proteins are up- or down-regulated. In addition, it is unlikely that one protein is responsible for a complex disease as HFpEF, but our findings offer new perspectives regarding HFpEF and further confirmation of the platelet proteins identified in this study will need to be validated in a larger cohort. In addition, combining proteomics with functional bioactivity assessments may be a strategy to complement and strengthen the search for biomarkers by combining protein identified with biological activity in a relevant in vitro model system.

In conclusion, from the discovery set in HFpEF patients, we derived a panel of platelet proteins that may be specific for HFpEF. Furthermore, this set distinguished a set of platelet proteins which are consistent in HFpEF subjects whether they are decompensated and hospitalized or compensated after discharge. We further established a bedside-to-bench translational system that can be utilized as a secondary screen to ascertain whether the biomarkers may be an associated finding or causal to the disease process.

(See figure on next page.)

Fig. 5 S100A8-mediated effects on human iPSC-derived cardiomyocytes. a Shows example action potentials recorded from rS100A8 treated iPSC derived human cardiomyocytes. The addition of rS100A8 to the buffer extended the period between action potentials. This period is phase 4; the diastolic membrane potential between action potentials. b rS100A8 exacerbates the arrhythmic tendencies of human cardiomyocytes. c Spontaneous $\mathrm{Ca}^{2+}$ transients recorded from human cardiomyocytes treated with rS100A8 as indicated by the blue line. rS100A8 significantly delayed the recovery of depolarization. Wash out of rS100A8 reversed these effects 


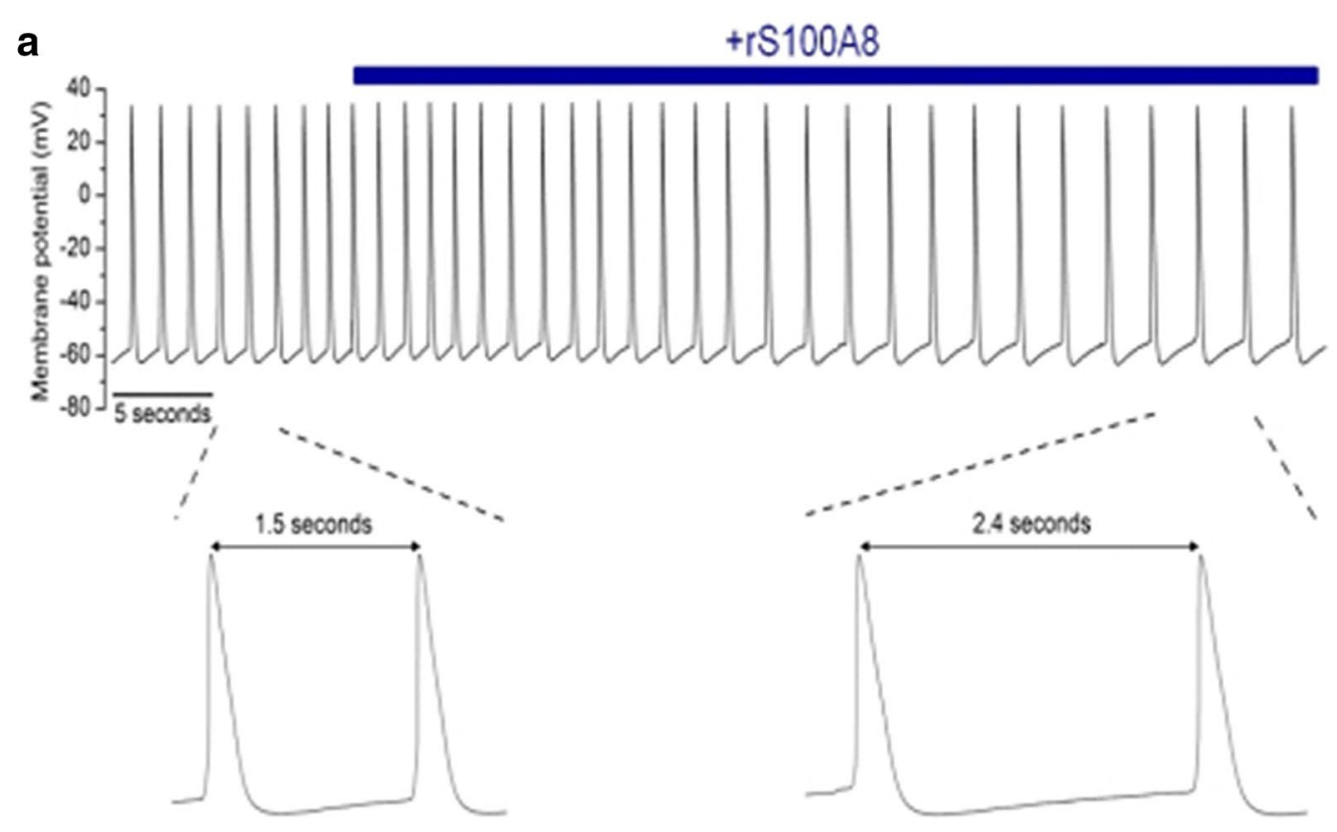

b
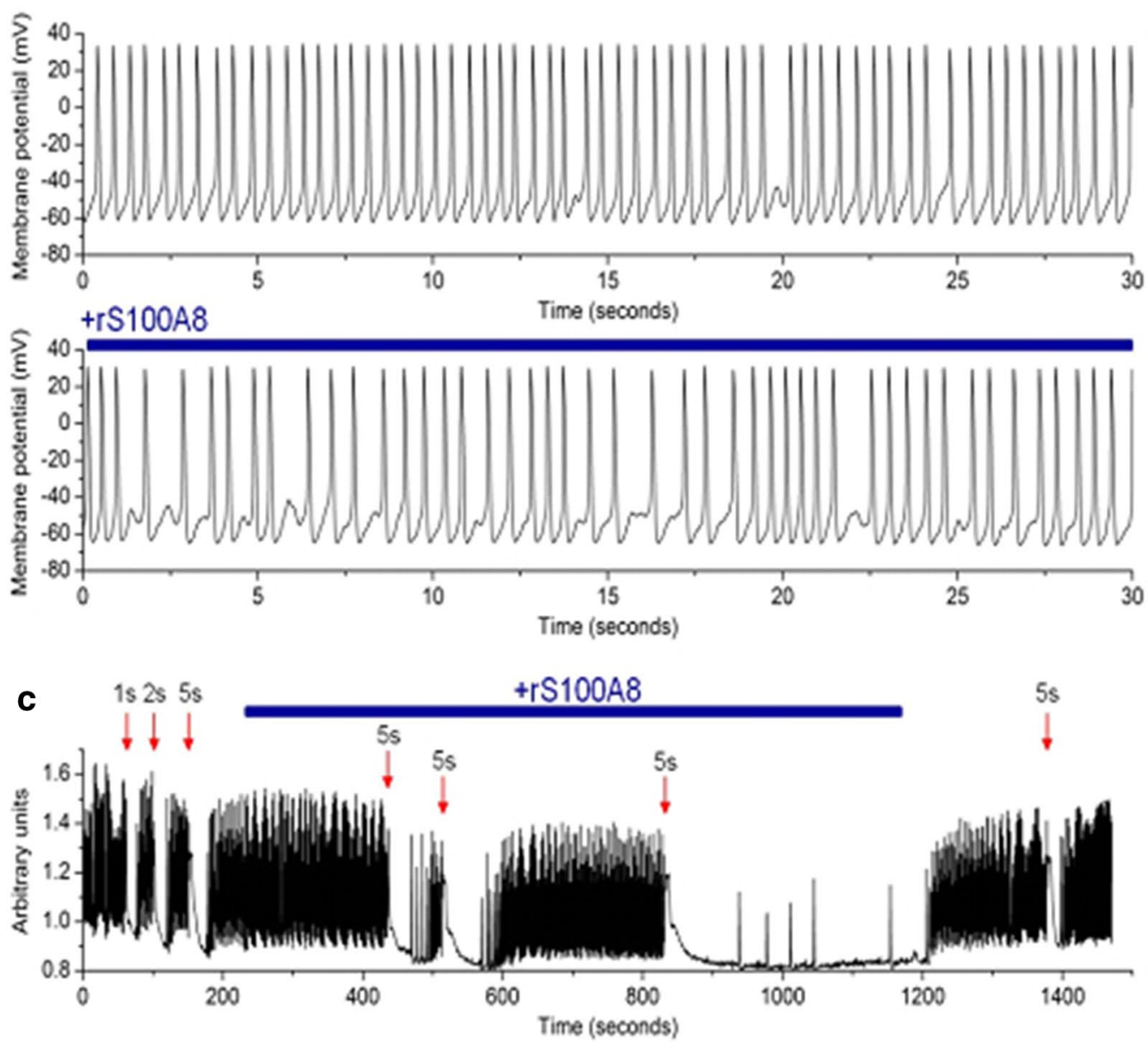


\section{Additional files}

Additional file 1: Figure S1. Flow cytometry to assess platelet activation. Purified platelet samples were incubated with fluorescently labeled antibodies against CD62P and CD41 and subject to flow cytometry. Platelets positive for CD41 + but negative for CD62P are non-activated. CD62P positive platelets are activated.

Additional file 2: Figure S2. Microscopy for Platelet Purity. Isolated platelets were observed under the microscope. Visible red blood cells and leukocytes were counted and calculated as a percentage of platelets in each field. Microscopy confirmation verified that the purified platelet had a leukocyte contamination $<0.02 \%$ and a red blood cell contamination of $<1 \%$.

\section{Authors' contributions}

JLS conceived and designed the research. RR, DP and SJS contributed clinical samples. SPM designed the proteomics experiments and MAC assisted in performing mass spectral analysis. RR, DP, JLS, WMK and HEW performed research and analyzed the data. RR DP and JLS drafted the paper and all coauthors edited the paper. All authors read and approved final manuscript.

\section{Author details}

${ }^{1}$ Cardiovascular Center, Medical College of Wisconsin, Milwaukee, WI, USA.

${ }^{2}$ Department of Medicine, Medical College of Wisconsin, Milwaukee, WI, USA. ${ }^{3}$ Division of Cardiovascular Medicine, Medical College of Wisconsin, Milwaukee, WI, USA. ${ }^{4}$ Present Address: MEB/CVC 4579, 8701 Watertown Plank Road, Milwaukee, WI 53226, USA. ${ }^{5}$ Biotechnology and Bioengineering, Medical College of Wisconsin, Milwaukee, WI, USA. ${ }^{6}$ Department of Anesthesiology, Medical College of Wisconsin, Milwaukee, WI, USA. ${ }^{7}$ Division of Cardiology, Department of Medicine, Northwestern University Feinberg School of Medicine, Chicago, IL, USA.

\section{Acknowledgements}

This work was supported by funds awarded to J.L.S. from the National Institutions of Health K08 Grant Number HL111148, Steve Cullen Healthy Heart Walk Run Event and also by grant 1UL1RR031973 from the Clinical and Translational Science Award (CTSI) program of the National Center for Research Resources, National Institutes of Health. We appreciate study subject referrals from Dr. Joshua Meskin and the biostatistics consulting services provided by Drs. Tao Wang and Shi Zhao from the Division of Biostatistics at the Medical College of Wisconsin.

\section{Competing interests}

The authors declare that they have no competing interests.

Received: 2 September 2015 Accepted: 6 January 2016

Published online: 20 January 2016

\section{References}

1. Banfi C, Brioschi M, Marenzi G, De Metrio M, Camera M, Mussoni L, et al. Proteome of platelets in patients with coronary artery disease. Exp Hematol. 2010;38(5):341-50.

2. Parguiña AF, Grigorian-Shamajian L, Agra RM, Teijeira-Fernández E, Rosa I, Alonso J, et al. Proteins involved in platelet signaling are differentially regulated in acute coronary syndrome: a proteomic study. PLoS One. 2010;5(10):e13404.

3. Springer DL, Miller JH, Spinelli SL, Pasa-Tolic L, Purvine SO, Daly DS, et al. Platelet proteome changes associated with diabetes and during platelet storage for transfusion. J Proteome Res. 2009;8(5):2261-72.

4. Veitinger M, Oehler R, Umlauf E, Baumgartner R, Schmidt G, Gerner C, et al. A platelet protein biochip rapidly detects an Alzheimer's diseasespecific phenotype. Acta Neuropathol. 2014;128(5):665-77.

5. Chung I, Choudhury A, Lip GY. Platelet activation in acute, decompensated congestive heart failure. Thromb Res. 2007;120(5):709-13.
6. Schafer A, Eigenthaler M, Bauersachs J. Platelet activation in heart failure Clin Lab. 2004:50(10):559-66.

7. Andreassi MG, Del Ry S, Palmieri C, Clerico A, Biagini A, Giannessi D. Upregulation of 'clearance' receptors in patients with chronic heart failure: a possible explanation for the resistance to biological effects of cardiac natriuretic hormones. Eur J Heart Fail. 2001;3(4):407-14

8. Chung I, Choudhury A, Patel J, Lip GY. Soluble, platelet-bound, and total P-selectin as indices of platelet activation in congestive heart failure. Ann Med. 2009:41(1):45-51.

9. Stumpf C, Lehner C, Eskafi S, Raaz D, Yilmaz A, Ropers S, et al. Enhanced levels of CD154 (CD40 ligand) on platelets in patients with chronic heart failure. Eur J Heart Fail. 2003;5(5):629-37.

10. Gurbel PA, Gattis WA, Fuzaylov SF, Gaulden L, Hasselblad V, Serebruany $V L$, et al. Evaluation of platelets in heart failure: is platelet activity related to etiology, functional class, or clinical outcomes? Am Heart J. 2002;143(6):1068-75.

11. UIHaq MA, Wong C, Hare DL. Heart failure with preserved ejection fraction: an insight into its prevalence, predictors, and implications of early detection. Rev Cardiovasc Med. 2015;16(1):20-7.

12. Putko BN, Wang Z, Lo J, Anderson T, Becher H, Dyck JR, et al. Circulating levels of tumor necrosis factor-alpha receptor 2 are increased in heart failure with preserved ejection fraction relative to heart failure with reduced ejection fraction: evidence for a divergence in pathophysiology. PLoS One. 2014:9(6):e99495.

13. Kalogeropoulos A, Georgiopoulou V, Psaty BM, Rodondi N, Smith AL, Harrison DG, et al. Inflammatory markers and incident heart failure risk in older adults: the health $\mathrm{ABC}$ (health, aging, and body composition) study. J Am Coll Cardiol. 2010;55(19):2129-37.

14. Smyth SS, McEver RP, Weyrich AS, Morrell CN, Hoffman MR, Arepally GM, et al. Platelet functions beyond hemostasis. J Thromb Haemost 2009:7(11):1759-66.

15. Heroux MS, Chesnik MA, Halligan BD, Al-Gizawiy M, Connelly JM, Mueller WM, et al. Comprehensive characterization of glioblastoma tumor tissues for biomarker identification using mass spectrometry-based label-free quantitative proteomics. Physiol Genomics. 2014;46(13):467-81.

16. Halligan BD, Greene AS. Visualize: a free and open source multifunction tool for proteomics data analysis. Proteomics. 2011;11(6):1058-63.

17. Si-Tayeb K, Noto FK, Sepac A, Sedlic F, Bosnjak ZJ, Lough JW, et al. Generation of human induced pluripotent stem cells by simple transient transfection of plasmid DNA encoding reprogramming factors. BMC Dev Biol. 2010;10:81

18. Lian X, Zhang J, Azarin SM, Zhu K, Hazeltine LB, Bao X, et al. Directed cardiomyocyte differentiation from human pluripotent stem cells by modulating Wnt/beta-catenin signaling under fully defined conditions. Nat Protoc. 2013;8(1):162-75.

19. Lian X, Hsiao C, Wilson G, Zhu K, Hazeltine LB, Azarin SM, et al. Robust cardiomyocyte differentiation from human pluripotent stem cells via temporal modulation of canonical Wnt signaling. Proc Natl Acad Sci. 2012;109(27):E1848-57.

20. Bhattacharya S, Burridge PW, Kropp EM, Chuppa SL, Kwok WM, Wu JC, et al. High efficiency differentiation of human pluripotent stem cells to cardiomyocytes and characterization by flow cytometry. J Vis Exp. 2014;91:52010.

21. Suzuki A, Aizawa K, Gassmayr S, Bosnjak ZJ, Kwok WM. Biphasic effects of isoflurane on the cardiac action potential: an ionic basis for anesthetic-induced changes in cardiac electrophysiology. Anesthesiology. 2002;97(5):1209-17.

22. Stoehr A, Neuber C, Baldauf C, Vollert I, Friedrich FW, Flenner F, et al. Automated analysis of contractile force and Ca2 + transients in engineered heart tissue. Am J Physiol Heart Circ Physiol. 2014;306(9):H1353-63.

23. Ma LP, Haugen E, Ikemoto M, Fujita M, Terasaki F, Fu M. S100A8/A9 complex as a new biomarker in prediction of mortality in elderly patients with severe heart failure. Int J Cardiol. 2012;155(1):26-32.

24. Schiopu A, Cotoi OS. S100A8 and S100A9: DAMPs at the crossroads between innate immunity, traditional risk factors, and cardiovascular disease. Mediators Inflamm. 2013;2013:828354.

25. Cotoi OS, Duner P, Ko N, Hedblad B, Nilsson J, Bjorkbacka H, et al. Plasma S100A8/A9 correlates with blood neutrophil counts, traditional risk factors, and cardiovascular disease in middle-aged healthy individuals. Arterioscler Thromb Vasc Biol. 2014;34(1):202-10. 
26. Wang Y, Fang C, Gao H, Bilodeau ML, Zhang Z, Croce K, et al. Plateletderived $\mathrm{S} 100$ family member myeloid-related protein- 14 regulates thrombosis. J Clin Invest. 2014;124(5):2160-71.

27. Morrow DA, Wang Y, Croce K, Sakuma M, Sabatine MS, Gao H, et al. Myeloid-related protein 8/14 and the risk of cardiovascular death or myocardial infarction after an acute coronary syndrome in the pravastatin or atorvastatin evaluation and infection therapy: thrombolysis in myocardial infarction (PROVE IT-TIMI 22) trial. Am Heart J. 2008;155(1):49-55.

28. Hirata A, Kishida K, Nakatsuji H, Hiuge-Shimizu A, Funahashi T, Shimomura I. High serum S100A8/A9 levels and high cardiovascular complication rate in type 2 diabetics with ultra sonographic low carotid plaque density. Diabetes Res Clin Pract. 2012;97(1):82-90.

29. Owan TE, Hodge DO, Herges RM, Jacobsen SJ, Roger VL, Redfield MM. Trends in prevalence and outcome of heart failure with preserved ejection fraction. N Engl J Med. 2006;355(3):251-9.

30. Bhatia RS, Tu JV, Lee DS, Austin PC, Fang J, Haouzi A, et al. Outcome of heart failure with preserved ejection fraction in a population-based study. N Engl JMed. 2006;355(3):260-9.

31. Ho JE, Lyass A, Lee DS, Vasan RS, Kannel WB, Larson MG, et al. Predictors of new-onset heart failure: differences in preserved versus reduced ejection fraction. Circ Heart Fail. 2013;6(2):279-86.

32. Burkhart JM, Gambaryan S, Watson SP, Jurk K, Walter U, Sickmann A, et al. What can proteomics tell us about platelets? Circ Res. 2014:114(7):1204-19.

33. Veitinger M, Umlauf E, Baumgartner R, Badrnya S, Porter J, Lamont J, et al. A combined proteomic and genetic analysis of the highly variable platelet proteome: from plasmatic proteins and SNPS. J Proteomics. 2012;75(18):5848-60.

34. Paulus WJ, Tschope C. A novel paradigm for heart failure with preserved ejection fraction: comorbidities drive myocardial dysfunction and remodeling through coronary microvascular endothelial inflammation. J Am Coll Cardiol. 2013;62(4):263-71.

35. Song B, Liu Y, Parman T, Liu S, Miller JK, Liu X, et al. Quantitative proteomics for cardiac biomarker discovery using isoproterenol-treated nonhuman primates. J Proteome Res. 2014;13(12):5909-17.

36. Wang DX, Liu H, Yan LR, Zhang YP, Guan XY, Xu ZM, et al. The relationship between serum amyloid $A$ and apolipoprotein $A-I$ in high-density lipoprotein isolated from patients with coronary heart disease. Chin Med J (Engl). 2013;126(19):3656-61.

37. Kim JB, Hama S, Hough G, Navab M, Fogelman AM, Maclellan WR, et al. Heart failure is associated with impaired anti-inflammatory and antioxidant properties of high-density lipoproteins. Am J Cardiol. 2013;112(11):1770-7.

38. Johnson BD, Kip KE, Marroquin OC, Ridker PM, Kelsey SF, Shaw LJ, et al. Serum amyloid $A$ as a predictor of coronary artery disease and cardiovascular outcome in women: the National Heart, Lung, and Blood InstituteSponsored Women's Ischemia Syndrome Evaluation (WISE). Circulation. 2004;109(6):726-32.

39. Healy AM, Pickard MD, Pradhan AD, Wang Y, Chen Z, Croce K, et al. Platelet expression profiling and clinical validation of myeloid-related protein-14 as a novel determinant of cardiovascular events. Circulation. 2006;113(19):2278-84.

40. Boyd JH, Kan B, Roberts H, Wang Y, Walley KR. S100A8 and S100A9 mediate endotoxin-induced cardiomyocyte dysfunction via the receptor for advanced glycation end products. Circ Res. 2008;102(10):1239-46.

41. Wu Y, Li Y, Zhang C, A X, Wang Y, Cui W, et al. S100a8/a9 released by $\mathrm{CD} 11 \mathrm{~b}+\mathrm{Gr} 1+$ neutrophils activates cardiac fibroblasts to initiate angiotensin II-Induced cardiac inflammation and injury. Hypertension. 2014;63(6):1241-50

42. Kuipers MT, Vogl T, Aslami H, Jongsma G, van den Berg E, Vlaar AP, et al. High levels of S100A8/A9 proteins aggravate ventilator-induced lung injury via TLR4 signaling. PLoS ONE. 2013;8(7):e68694.
43. Schelbergen RF, Blom AB, van den Bosch MH, Sloetjes A, Abdollahi-Roodsaz S, Schreurs BW, et al. Alarmins S100A8 and S100A9 elicit a catabolic effect in human osteoarthritic chondrocytes that is dependent on tolllike receptor 4. Arthritis Rheum. 2012;64(5):1477-87.

44. Ghavami S, Rashedi I, Dattilo BM, Eshraghi M, Chazin WJ, Hashemi M, et al. S100A8/A9 at low concentration promotes tumor cell growth via RAGE ligation and MAP kinase-dependent pathway. J Leukoc Biol. 2008;83(6):1484-92.

45. Volz HC, Laohachewin D, Seidel C, Lasitschka F, Keilbach K, Wienbrandt AR, et al. S100A8/A9 aggravates post-ischemic heart failure through activation of RAGE-dependent NF-kappaB signaling. Basic Res Cardiol. 2012;107(2):250

46. Ortega FJ, Sabater M, Moreno-Navarrete JM, Pueyo N, Botas P, Del-

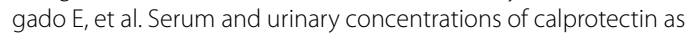
markers of insulin resistance and type 2 diabetes. Eur J Endocrinol. 2012;167(4):569-78.

47. Tribouilloy C, Rusinaru D, Mahjoub H, Souliere V, Levy F, Peltier M, et al. Prognosis of heart failure with preserved ejection fraction: a 5 year prospective population-based study. Eur Heart J. 2008;29(3):339-47.

48. Lindman BR, Davila-Roman VG, Mann DL, McNulty S, Semigran MJ, Lewis GD, et al. Cardiovascular phenotype in HFpEF patients with or without diabetes: a RELAX trial ancillary study. J Am Coll Cardiol. 2014;64(6):541-9.

49. Maličková K, Brodská H, Lachmanová J, Dusilová Sulková S, Janatková I, Marečková $\mathrm{H}$, et al. Plasma calprotectin in chronically dialyzed end-stage renal disease patients. Inflamm Res. 2010;59(4):299-305.

50. Han JH, Han JS, Kim EJ, Doh FM, Koo HM, Kim CH, et al. Diastolic dysfunction is an independent predictor of cardiovascular events in incident dialysis patients with preserved systolic function. PLOS ONE. 2015;10(3):e0118694.

51. Cayatte C, Joyce-Shaikh B, Vega F, Boniface K, Grein J, Murphy E, et al. Biomarkers of therapeutic response in the IL-23 pathway in inflammatory bowel disease. Clin Trans Gastroenterol. 2012;3:e10.

52. Caliskan Z, Gokturk HS, Caliskan M, Gullu H, Ciftci O, Ozgur GT, et al. Impaired coronary microvascular and left ventricular diastolic function in patients with inflammatory bowel disease. Microvasc Res. 2015:97:25-30.

53. Yan D, Luo X, Li Y, Liu W, Deng J, Zheng N, et al. Effects of advanced glycation end products on calcium handling in cardiomyocytes. Cardiology. 2014;129(2):75-83.

54. Iwaya S, Oikawa M, Chen Y, Takeishi Y. Phosphodiesterase 3A1 protects the heart against angiotensin II-induced cardiac remodeling through regulation of transforming growth factor- $\beta$ expression. Int Heart J. 2014;55(2):165-8.

55. Hordyjewska A, Popiolek L, Kocot J. The many "faces" of copper in medicine and treatment. Biometals. 2014;27(4):611-21.

56. Feng $Y, W u H, X u Y$, Zhang Z, Liu T, Lin $X$, et al. Zinc finger protein 451 is a novel Smad corepressor in transforming growth factor- $\beta$ signaling. J Biol Chem. 2014;289(4):2072-83.

57. Knowles H, Li Y, Perraud A-L. The TRPM2 ion channel, an oxidative stress and metabolic sensor regulating innate immunity and inflammation. Immunol Res. 2013;55(1-3):241-8. 